\title{
Research on tourism innovation marketing in the era of WeChat Ying MENG
}

\author{
School of Economics and Management, Wuhan University, Hubei Wuhan, 430072
}

Keywords: era of WeChat; information technology; tourism development; tourism industry; marketing

\begin{abstract}
Based on specific cases and relevant theories of WeChat sales, the new tourism marketing mode in era of WeChat - the role of tourism WeChat marketing in tourism information service is discussed in the Thesis according to specific cases and the corresponding development countermeasures are proposed according to the specific problems. In the Thesis, the discussion is centered on WeChat marketing, the text analysis and case study are combined and the scientific and reasonable suggestions and countermeasures are proposed through analyzing advantages and disadvantages of cases to drive the development of tourism industry.
\end{abstract}

\section{Introduction}

The independent tourists pay more attention to flexibility, diversity and independence of the tourism activity and rely on the public service of tourism much stronger. Under the background of rapid development of independent tourists and personalized tourism, the strengthening and improving of public service for tourism has become a urgent and important task for various levels of tourism management departments. The emerging socialized media will occupy more and more important position under the background of rapid development of Internet. The socialized media such as blogs, online social network (such as Facebook), Podcast, content community, forum, Weibo (such as Twitter and Sina Weibo) increasingly become the import part to affect the social development and the rapid development of Weibo gives rise to a "new era".

\section{WeChat marketing theory}

Directmarketing theory. Directmarketing is a direct channel for product and service sales between the company and the consumers and a series of sales methods with the intermediate links reduced. Directmarketing is of the features such as cross-time and space, interactivity, one-to-one service and predictable marketing effect. Directmarketing is a method to realize one-to-one information exchange and communication between the enterprises and consumers through Internet. The consumers can purchase according to the product information and the enterprises can learn the demands of the customers from their information, so the cost can be reduced through operation and management as required.

Integrated marketing theory. Integrated marketing means that the enterprises learn the information through communication with the consumers and then make the customers quickly find the desired information through unified application and coordination of various communication methods which is favorable to the establishment of long-term relation with consumers.

Database marketing theory. Database marketing theory means the marketing method to conduct in-depth customer uncovering through targeted application of many manners such as e-mail, telephone, text and letters based on the systematic analysis and collection of detailed information and data for various customers which are collected and accumulated during corporate business and serve as the marketing strategy.

\section{Basic modes of WeChat marketing}

Enterprises must first understand the basic modes of WeChat marketing to take advantage of the WeChat marketing and the development progress of current WeChat marketing. 
Mode I: "searching nearby people". The marketing mode of promoting LBS is based on the geographic position and users can click "nearby people" to search all the nearby WeChat users, so users can publicize their product information through this. In case the nearby WeChat scope is expanded, the functions of map display, topping function of LBS sign will be promoted and then the period bidding listing mode will be adopted which is typical of LBS marketing.

Mode II: current bottle. Take the "current bottle for love" of Commercial Bank as an example. Users can conduct simple interactivity through "current bottle" or the picked current bottle of Commercial Bank and the Commercial Bank can help the autistic children through the platform of "small credits and micro charity". The action can not only cultivate a large amount of potential customer base, but also can increase the popularity of the Commercial Bank which kills two birds with one stone.

Mode III: scanning; at present, it is the main sign of WeChat and meanwhile the "O2O" is opened; according to the current procedure of WeChat, users only need to scan the QR code of the merchants and you will have a electronic membership card saved in WeChat to enjoy the discount and service provided to members by the merchants. It can be concluded that QR code is the key to turn from the online to offline.

Mode IV: open platform + circle of friends; WeChat allows the merchants to introduce and promote their own applications on the open platform; take Meilishuo-the earliest partner of open platform as an example; users publicizes the commodities of Meilishuo one by one through WeChat to increase the product popularity. From the perspective of communication, the share function for circle of friends is an interpersonal communication and it provides the opportunity of sharing self-emotion to users; even the advertisement information of merchants can be included.

Mode V: WeChat public platform is a product with extensive concern of media; because of its large expansion space, so it attracts much attention of enterprises. The Platform can promote the information such as news, product information and latest activity to users through WeChat public platform; besides, the functions including user consultation and customer service can be completed which is equivalent to the CRM system of the enterprises.

Analysis of the several marketing modes can be simplified in the following table:

\begin{tabular}{|l|l|l|l|}
\hline \multicolumn{4}{|c|}{ Table Basic Modes of WeChat Marketing } \\
\hline Marketing modes & Advantages & Defects & Applicable scope \\
\hline $\begin{array}{l}\text { searching nearby } \\
\text { people }\end{array}$ & $\begin{array}{l}\text { Effectively attract } \\
\text { nearby users }\end{array}$ & $\begin{array}{l}\text { The searching scope is } \\
\text { small }\end{array}$ & $\begin{array}{l}\text { Merchants such as } \\
\text { shops, restaurants and } \\
\text { hotels determined by } \\
\text { the geographic } \\
\text { position }\end{array}$ \\
\hline Current bottle & $\begin{array}{l}\text { It is a matter of lottery } \\
\text { with strong feasibility }\end{array}$ & $\begin{array}{l}\text { The marketing cannot } \\
\text { be targeted at target } \\
\text { customer groups }\end{array}$ & $\begin{array}{l}\text { The enterprises with } \\
\text { relatively high brand } \\
\text { awareness can expand } \\
\text { its popularity through } \\
\text { this }\end{array}$ \\
\hline Scanning & $\begin{array}{l}\text { It is of game sign with } \\
\text { strong pertinence }\end{array}$ & $\begin{array}{l}\text { Users must actively } \\
\text { operate }\end{array}$ & $\begin{array}{l}\text { Products conform to } \\
\text { the requirements of } \\
\text { users }\end{array}$ \\
\hline $\begin{array}{l}\text { open platform + circle } \\
\text { of friends }\end{array}$ & $\begin{array}{l}\text { Word-of-mouth } \\
\text { marketing and wide } \\
\text { publicity }\end{array}$ & $\begin{array}{l}\text { More requirements are } \\
\text { put forward for } \\
\text { products, otherwise } \\
\text { the users will not } \\
\text { share }\end{array}$ & $\begin{array}{l}\text { Enterprises possessing } \\
\text { highly mature } \\
\text { products and services }\end{array}$ \\
\hline $\begin{array}{l}\text { WeChat public } \\
\text { platform }\end{array}$ & $\begin{array}{l}\text { A staggering amount } \\
\text { of information }\end{array}$ & $\begin{array}{l}\text { Disturbing marketing } \\
\text { easily make users } \\
\text { bored }\end{array}$ & $\begin{array}{l}\text { Enterprises with } \\
\text { relatively mature } \\
\text { online businesses }\end{array}$ \\
\hline
\end{tabular}




\section{Private customized WeChat services}

WeChat is more than a tool for marketing and information display; more importantly, it is a deliverer of inherent culture and value of an enterprise. Personality is what network needs, and a person having his/her own attitude and opinions would be far better received than those who don't. Therefore, enterprise should state its very own opinions and build its very own characters on the WeChat. Thus, being emotional and personalized to enable netizens to know more about and trust more deeply in the enterprise culture and value. Therefore, tourism-oriented Wechat accounts should, besides pushing normal information, get itself involved in discussion on social hotspots and express its viewpoints; or otherwise showing work or lifestyle of its employees. Integrated marketing is integration of several separate marketing by systemizing marketing tools and means as well as real-time dynamic correction based on environment for the purpose of synergistic effect. WeChat plays an important role in tourism marketing as it enables users to get to know the travel destination and helps finding potential tourists. Resources integration realized by WeChat mainly involves integration of tourism market and tourism information, thus building a bridge to connect the place where a tourist is from and his/her travel destination. On the one hand, users may be inspired to take a trip when forwarding and searching on WeChat. In America, a country where internet has been well developed, tourism-oriented WeChat marketing fails to replace traditional marketing as people still prefers conventional media such as newspaper, TV and travel magazines for travel information. Therefore, WeChat, in terms of tourism marketing, would be the most suitable tool for integrated marketing for its rapidness and wideness in information release and communication.

\section{Conclusion}

As the new communication media, WeChat has been used in marketing of tourism enterprises; due to the characteristics such as convenient application, instant information, wide communication scope and interactivity of WeChat, it attracts many fans, sufficiently plays the role of new media and provides help for more comprehensive development of tourism enterprises; at present, WeChat has become the indispensable tool in people's life. You can imagine that in life with mobile Internet, the restaurant can be selected through WeChat, the water, electronic and communication charges can be paid through WeChat, go shopping and paid through WeChat, go to hospital and register through WeChat and order the ticket through WeChat, so the development of WeChat can never be ignored. For middle and small-sized merchants, the application of WeChat in marketing is just starting and not mature; what you need now it your peculiar value. So to speak, it is irrelevant to business mode, because all the media, merchants, individuals as well as the big and small brands can develop in the platform of WeChat.

It is open to discussion whether WeChat marketing can bring tangible benefits to each enterprise. But as increasingly growing of WeChat marketing group, entrepreneurs successively create their own WeChat marketing platforms, so the large amount of WeChat users definitely provide infinite possibility and opportunity to development of WeChat marketing; it can be predicted that WeChat is becoming the mainstay in network marketing.

\section{Reference}

[1] Brea J A F, Brea J A F. The constant evolution of tourism: innovation, technology, new products and experiences.[J]. Pasos Revista De Turismo Y Patrimonio Cultural, 2015.

[2] Taher S H M, Jamal S A. Determinants of mountaineers' decision to climb: An innovative marketing for mountaineering tourism[C]// Innovation Management and Technology Research (ICIMTR), 2012 International Conference on. IEEE, 2012:646-651.

[3] Rodríguez Fernández M, González Sánchez R, García Muiña F E. The role of mobile 
technology in the innovation process of tourism enterprises: proposal for an integrated management model.[J]. 2012, 33(3):341-349.

[4] Dibrell C, Davis P S, Craig J. Fueling Innovation through Information Technology in SMEs *[J]. Journal of Small Business Management, 2008, 46(2):203-218.

[5] Mistilis N, Buhalis D, Gretzel U, et al. Future eDestination Marketing: Perspective of an Australian Tourism Stakeholder Network[J]. Journal of Travel Research, 2014, 53(1):92830S-92830S-6. 